\title{
特集 マンションの新たな課題と管理のありかた【論説】
}

\section{専門家の活用の必要性と課題}

The Use of Experts : Necessity and Challenges

Satoru OYADOMARI : Chairperson, Japan Federation of

Legal Licensed Condominium Managers' Associations

親泊 哲*

\section{口管理組合という組織の特性と専門家活用 の必要性など}

管理組合は，区分所有者という人の集団であり， 数十人の集団であることはごく普通で, 数百人の 集団であることも珍しくない。

それだけの規模の人の集団であれば，マンショ ンを管理するために求められる各方面の分野の専 門性を備えた人材が区分所有者の中に存在してい る(埋もれている) 可能性が当然考えられる。

しかし，まず，区分所有者の英知を結集するこ とはできる一方, 日常の業務運営にしても, 特定 の事業運営にしても, 少数の区分所有者に過度の 負担がかかるようなことには, 何かと問題がある 組織である。

特に, 専門性を備えた区分所有者が仮にあると しても，管理組合の役員や専門委員としての活動 が決して職業的に行うものではない以上, 自分の 居住空間（区分所有関係下）で発揮し得る専門性 には自ずと限界があるほか，何か問題があったと き，その区分所有者の責任を追及するようなこと が馴染まない組織である。

また，基本的に本業を持っている者らで構成さ れ，大半の者が限られた時間の中で役員等を引き 受けている組織にあって, 区分所有者全員が均質 なレベルでマンションの管理に関する専門的知識 を習得するようなことなども馴染まない。
さらに，管理組合の会計は，マンションの管理 や管理組合の運営について, 最小の費用で最大の 効果を上げることを目的としている中，ここにい う「最大の効果」の中には, 団体的に「安心でき ること」や「煩わしくないこと」が含まれる必要 がある。

一方，区分所有者同士は，お互いがマンション を所有し続ける限り, 常に当事者の関係にあるほ か，管理組合と管理会社についても，管理委託契 約に拘束される限り, 当事者の関係にある。

ここにいう当事者の関係とは，利害を有する関 係であり，どちらも第三者にはなれない関係であ る。

当事者同士は，利害にとらわれるあまり，時と して真に指摘しあわなければならないことを指摘 しあえなかったりする点は, 何もマンションの管 理や管理組合の運営に限ったことではない（世の 常）と考えられる。

以上のことを考慮した場合, マンションを管理 するうえで, 当事者では解決が難しい問題が生じ たときなどには, 必要に応じて, そのマンション について何ら利害関係を有しない外部の専門家に その運営に関与してもらい, 問題点を毅然と指摘 してもらったり，管理組合の運営を支援しても らったりすることが有用という結論を導くことが でき，国土交通省が公表しているマンション標準 管理規約にも, マンション管理士をはじめとする 
専門的知識を有する者の活用に関する条項（第34 条／単棟・団地・複合用途の各夕イプに共通）が 置かれて久しい。

そして, マンション管理適正化法（以下「適正 化法」と記す。）に規定されたマンション管理適 正化指針（第 3 条），管理組合と区分所有者の努 力義務 (第 4 条) などによって示唆される「マン ション管理の主体性」の観点からも, 必要性を感 じた管理組合側が自ら積極的に専門家活用の行動 を起こすべきと考えられる。

\section{ロコンサルタントとしての専門家の活用}

大規模修繥工事，管理規約の改定，管理会社と の管理委託契約の見直しなど，管理組合で実施さ れる特定の事業運営のほか, 管理組合の日常の業 務運営全般について, 次のようなことを期待し, 外部の専門家をコンサルタントや顧問（主に助言 指導者）として活用することが考えられる。

$\bigcirc$ 区分所有者間の合意を得るために必要 となる専門的な知識やノウハウを提供

\section{してほしい（専門性の確保）}

検討に参加することができる時間が限 られている者ばかりなので，効率のよ い会議運営（検証作業の実施）を計画

\section{してほしい（効率性や合理性の確保）}

$\bigcirc$ 特定の者の意見や意向, 関係者間の感 情やしがらみなどに流されることのな い冷静かつ客観的な判断・分析を行っ てほしい（関係者の恣意の排除＝公正 性や透明性の確保)

上記において，コンサルティングの対象を一言 で記せば，「理事会の区分所有者に対する説明責 任の完遂のサポート」になる。

ここにいう説明とは, マンションの管理や管理 組合の運営の一時が万事につき，理事会が「そう することを最良と判断した検討経過や理由」の説 明である。
つまり，日常の業務運営にしても，特別の事業 運営にしても，理事会や専門委員会が尽くすべき 「必要な注意」とともに，それが尽くされること による「団体の合意形成 (総会の承認決議)」を サポートするのがコンサルタントの役割・使命と 言え，そのために，管理組合はコンサルタント業 務委託費や顧問料を負担する関係にあると考える ことができる。

コンサルタントに求められる要件等については, 後述するが，以上のことを反対に考えた場合，理 事会の区分所有者に対する説明責任の完遂をサ ポートし得ないような者は, コンサルタントとし て求められる最低の要件を欠く。

一方, コンサルタントや顧問は, 理事会の区分 所有者に対する説明責任の完遂をサポートするが， もともと管理組合運営上の当事者ではないため, 管理組合の業務運営について最終的な責任までを 負う立場にはない。

したがって，管理組合の理事会に，「区分所有 者に対して説明を尽くそう」という責任感（熱意 や当事者意識)，コンサルティングの成果の有用 性を判断し得る能力のほか, そのための気力や体 力のあることが，コンサルタント活用の絶対的な 要件になると考えられる。

\section{口当事者としての専門家の活用}

上記のとおり，区分所有者や管理会社だけでは 解決できない懸案について, 外部の専門家にコン サルティングを依頼するという選択肢があるのに 対し, 専有部分の賃貸化や役員の高齢化などに よって役員のなり手不足が深刻な管理組合では, 理事会に責任感 (熱意や当事者意識), コンサル ティングの成果の有用性を判断し得る能力, その ための気力や体力を求めること自体に無理がある など，専門家をコンサルタントとして活用する以 前の問題があり，これらの点については，もはや 当事者の区分所有者間では解決できない問題と位 置付けられるケースも多い。

一方，マンションが建っている限り，いつのと 
きもそれを適切に管理することが団体的に求めら れている。

以上の関係から, 特に賃貸化や高齢化によって 役員のなり手不足が深刻な管理組合において, マ ンションの管理に関するコンサルタント経験やノ ウハウが豊富な外部の第三者を管理組合運営上の 当事者（管理者や役員等）の地位に据え, その業 務運営について最終的な責任までを負ってもらい たいというニーズが生じ得ることになる。

ここにおいて，管理組合運営上の当事者は, 法 制度上の当事者と，規約上の当事者に分類できる。

1. 法制度上の当事者

区分所有者の団体（管理組合）の管理者（区 分所有法第25条)

団地建物所有者の団体（団地管理組合）の管 理者（同第66条で準用する第25条）

管理組合法人の理事または監事（同第49条〜 第51条)

団地管理組合法人の理事または監事（同第66 条で準用する第49条〜第51条)

2. 規約上の当事者 (区分所有法第30条第 1 項ま たは同第66条で準用する第30条第 1 項)

区分所有者の団体（管理組合）の規約に定め られた理事または監事

団地建物所有者の団体（団地管理組合）の規 約に定められた理事または監事

自主管理マンションの管理組合の事務局専従 者 (事務局長) など

その他

なお，平成28年 3 月 14 日に公表されたマンショ ン標準管理規約改正版（巻末部の別添 1 ）におい て，外部の専門家が「当事者」として活用される 場合のパターンが次のとおりに示されることに なったので，ぜひ併せて参照していただきたい。

(1)理事・監事外部専門家型又は理事長外部専門家 型

(2)外部管理者理事会監督型

(3)外部管理者総会監督型

管理組合の管理者や役員に就任した外部の専門
家は，対外的には「当事者」とならざるを得ない が, 内部的には，区分所有関係に拘束されない点 で，いつのときも第三者（他人）である。

管理組合の管理者や役員が区分所有者である場 合，当事者に当たる立場から業務を遂行せざるを 得ないことで, 特に多額のお金がかかる事案の推 進などが消極的なものとなりがちだが, 外部の専 門家は, 区分所有関係を考慮した気兼ねなどを要 しない中でマンションの将来を冷静に考慮, 予測, 判断し, 必要に応じて忌憚のない提案や意見等を 呈することができる。

そして，ここまでは，コンサルタントに求めら れている点と同じだが，当事者としてそれらを 肃々と推進, 遂行することができることにもなる 点が決定的に異なることになる。

また，当事者となることで，法律への抵触がな い範囲内において, 外部との交渉や折衝などを直 接的に行うことができるようになると考えられる。

一方, 適正化法が要請している「主体性」との 関係からも，管理組合にとって，当事者としての 専門家の活用は，あくまで「万策尽きた場合の セーフティーネット」の位置付けとなることが理 想である。

言い換えれば，その管理組合において，専門家 を当事者として活用せずとも管理・運営の活性化 を図ることができる可能性（=他の方法）に対す る検討や検証が十分に尽くされ，かつ，専門家を 当事者として活用することが自分達にとって最良 の選択に当たると判断された結果に基づいて活用 される必要がある。

世の中の関心度や注目度からも,「専門家」と 位置付けられる者や，これらの者を構成員とする 団体は，これを安請け合いしたり，安易なビジネ スモデル等と捉えるようなことがないように心掛 ける必要がある。

\section{口活用上の課題の考察（専門家に備わって いるべき要件)}

コンサルタントとして活用する場合も, 当事者 
として活用する場合も, 外部の専門家は管理組合 によって主体的に選ばれて活用される関係にある。

そこで, 選ぶ際の基準となり得る「専門家に備 わっていることが望ましい要件」に着目し, 活用 上の課題を考えてみる。

マンション管理士資格しか有しない筆者の立場 から，他の専門家の要件に言及するようなことは， いささかおこがましいため, 必要に応じてマン ション管理士を例に挙げて以下を考察するものだ が, 結論として，ここにいう要件は，いずれの専 門家についても共通していると考えられる。

\section{1．専門性}

マンションの管理や管理組合の運営に関する専 門性が担保されたマンション管理士の国家試験は, 「マンション管理士として必要な知識について行 う。」とされている（適正化法第 7 条第 1 項）。

一方, 管理組合の運営に助力する専門家は, 管 理組合が執り行う特定の事業運営や日常の業務運 営に関し，どのような点に気をつけてそれらを進 めたらよいか？…といったことに対する知識やノ ウハウを備えていることが求められるが，これら の大半は, 試験に合格するための勉強を通じて得 られる知識やノウハウ（専門性）に当たらない。

実際のところ, 専門性が担保されたマンション 管理士でさえ，こうした知識やノウハウを含めた 専門性を, マンションの管理や管理組合の運営に 対するコンサルティングの経験を重ねることに よって培い，補完するスケジュールになる。

異なる視点から, 責任を伴ったコンサルティン グを期待するうえで，マンションの管理や管理組 合の運営について，単に物事をよく知っている （知識が豊富である）ことと, 第三者（=非当事 者）として団体の合意形成をサポートすることが できるコンサルティング能力をも有することとは 全く別であることが，活用する側に正しく認識さ れる必要がある。

管理者や役員など，当事者として活用される専 門家についても，基本的に同じことが言えるとと
もに，この専門性は，「経験則」などとは明確に 区別されなければならない。

\section{2. 実務経験や専念性}

専門家の実務経験は, 自己申告に基づく経験年 数や実績件数の表示のみではなく, 客観性と具体 性を伴った内容であることが求められる。

単なる年数や件数の表示のみによっては，それ らの数字が大きい者の方が相対的に高評価を獲得 する関係にあるが，活用する側にとっては，自分 達の期待に応えてくれる者かどうか，その者に対 するコンサルタントや管理者等の業務の委託が 「最小の費用で最大の効果を上げ得るかどうか」 を見極めなければならないのだから，その判断を 誤らないためにも, 実務経験のほか専念性が具体 的に示される必要がある。

特に, そのマンションについて生じている問題 と類似の問題に対するコンサルティング等を行っ た実績が明らかな専門家であれば，その者との契 約を内定する有力な理由になり, 理事会の区分所 有者に対する説明も説得力を伴う関係にある。

また，専念性という点で，マンション管理士の 場合，管理組合の相談対応業務や，管理組合の依 頼に基づくコンサルタント業務については，必ず しもマンション管理士を本業としていない者に よっても対応し得ると考えられる。

これに対し，管理者をはじめとする当事者の業 務については，それに伴う責任からも，これを片 手間に行うようなことは，ちょっと考元難く，ま た，管理組合側にも受け容れられないと考えられ る。

そのため, あまり一般的ではないが，その者の 確定申告書や決算書（あくまで最低限の数字の部 分のみ）の写しの提出を求めてみるようなことが 考えられる。

\section{3. 信用性}

マンション管理士の場合, 法律上も守秘義務や 信用失墜行為の禁止義務を負った資格者として職 
務を遂行し，万一にも依頼者の信頼に背いたり， 無責任なコンサルティング等に興じるようなこと があれば, 資格名の使用停止, 最悪の場合にはマ ンション管理士の登録の取り消しといった厳しい 処分を受け得る立場にある。

そして，実際にそうしたことがあれば，職業人 としても致命的な社会的制裁を受け得る立場にあ ることが「信用」に当たると考えられる。

信用という点では, 個人より法人 (組織) の方 が適格と考えられがちだが，もともとマンション 管理士資格は，個人のみに与えられる資格である。

また，仮に法人の社員（構成員）にマンション 管理士資格を有する者があったとしても，管理組 合があくまで法人と契約する関係に照らせば，こ こで資格者である社員個人の能力に期待できるこ とにも限界がある点で, 必ずしも個人の信用が法 人と比べて低いわけではないことが活用する側に 正しく理解される必要があると考えられる。

\section{4. 第三者性}

第三者性とは，区分所有関係に拘束されない他 人として職務を遂行し得る立場や，管理組合や 個々の区分所有者との間においても，契約業務以 外の契約に拘束されることがない（基本的に利害 関係を有しない) 状態で, 職務を遂行し得る立場 を指す。

逆に, もしコンサルタントや管理者と管理組合 （または特定の区分所有者）との間に契約業務以 外の別の契約が存在する場合, その利害関係（当 事者性）に起因して，コンサルタントや管理者の 職務遂行に求められる「関係者の恣意の排除」が 心許ないものとなったり, いわゆる利益相反関係 が構成される可能性が容易に考えられる。

具体的には, 例えば, 専門業者の見積参加を伴 う管理組合の事業運営（管理委託契約の見直しや 大規模修絟工事の事業など）において，コンサル タントたる専門家の利害関係先の会社や団体の推 薦, 当該社に対する発注指南などが行われること で，管理組合の事業運営の公正性が害されること
などが懸念される。

また，例えば，管理組合の管理者となったAが 管理事務や改修工事を受注し得る会社（管理会社 や建設業者)Bの代表者でもある場合において， $\mathrm{AB}$ 間で管理委託契約や工事請負契約が締結され るようなことになれば, Aは, 一方では管理組合 の代表者として, 他方ではBの代表者として, 当 事者間で自分勝手な取引を成立させ, 管理組合に 不測の損害を生じさせる可能性などが懸念される。

そして, 前記の利害関係については, 表立って 明らかになっている関係と, 必ずしもそうではな い関係とが存在するため, 活用する側としては, 必ずしも明らかになっていない利害関係までをも あらかじめ開示してもらう必要があることになる ものの, ここで細部の見極めまでを行うことは困 難である。

結局のところ，管理組合の契約の相手方となり 得る周辺業を兼業 (兼営) する立場にないことの 確認のほか, 本編で例示した他の要件にも照らし, 第三者性を欠く可能性が限りなく低い者であるこ とを総合的に判断することになると考えられる。

\section{口第三者管理者方式（理事会廃止型）によ る管理・運営上の課題など}

最後に, 理事会が廃止された管理組合で, 外部 の専門家を第三者管理者（以下，単に「管理者」 と記す。）として活用するケースに特化した課題 や克服策などを記す。

\section{1. 管理者の業務執行のチェック体制の構築（監 査機能の確保)}

区分所有法は，管理者の事務の執行について， 毎年一回, 一定の時期に開かれるべき区分所有者 の集会（通常総会や定時総会）で区分所有者に報 告させる義務のみを負わせているが, これでは チェック不足に陥る可能性がある。

理事会制度下の運営においては, 理事の業務の 執行や, 管理組合の財産の状況を監査する役員と して監事が選任されるのが一般的だが，これと同 
じ観点から，管理者の業務遂行状況をチェックす るための仕組みを規約の定めを通じて構築するこ とが望ましいと考えられる。

\section{2. 金銭管理を行い得る者や印鑑を保管する者の 制限（事故防止策の確保）}

適正化法は, 部外者で管理組合の基幹事務を包 括的に受託し得る者を「マンション管理業の登録 を受けた者」に限定している。

この関係から，第三者管理への移行後において， 管理組合の現金や預金を取り扱う出納業務に限っ ては，必ずマンション管理業の登録を受け，かつ， 賠償能力を備えた者に委託して実施することが求 められると考えられる。

一方, 特別な場合を除き, 管理組合の修繥積立 金を保管する預金口座（保管口座）の印鑑をマン ション管理業者が保管することが禁じられている ため, 保管口座の印鑑は管理者が責任をもって保 管せざるを得ないケースが多いと思われる。

結論として, 少なくとも法律上の役割や責任関 係が明らかではない者に対して，保管口座の印鑑 の保管を含めた金銭の管理を委託するべきではな いと考えられる。

\section{3. 管理者に対する総会の議決権行使の委任の制 限（形骸化防止策の確保）}

第三者管理者方式下においては, 導入後の安心 感も相まって, 区分所有者の総会出席率（議場へ の出席率）がかんばしくなくなる可能性が考えら れる。

こうした中にあって元来, 区分所有関係にない 管理者に対する総会の議決権行使の委任が集中し たのでは, 管理組合運営の根幹とも言える総会運
営が形骸化し，管理者の業務遂行に対する最低限 のチェック機能すら働かなくなるおそれがある。

そのため, 管理者に対して総会の議決権行使が 委任されないようなルールの設定が求められると 考えられる。

\section{4. 管理者が辞任または退任する場合等のルール の明確化（継続性の確保）}

任期中の管理者に死亡, 疾病等の事情が生じ, 管理者としての職務の遂行が不可能または著しく 困難となる可能性が考えられる。

こうした可能性に備えて，管理に空白期間を生 じさせないためのルール（後任者に関するルール など）をあらかじめ取り決めておく必要がある。

一例として，管理者Aに万一の事情が生じた場 合には，その任期の終期までの期間内において， 同等の専門性を有するBが後任として継続的に管 理者の業務を履行すること（または履行保証契約 の存在に関すること）などをあらかじめAと管理 組合の業務委託契約に定めるような方法が考えら れる。

\section{5. 管理者の利益相反関係の排除（取引の健全性 の確保)}

利益相反関係の基本事項については, 前頁 4 . 第三者性に記述したとおりである。

管理組合の与り知らぬところで健全性を欠いた 取引がなされることを防止するため, 総会の承認 を得た場合を除き，管理者が管理者業務以外の業 務の契約の相手方になることを制限する旨のルー ルを規約に定めて運用するような方法が考えられ る。

以上 